УДК 94(510).06

DOI: $10.22378 / 2313-6197.2017-5-4.770-785$

\title{
THE TŪQMĀQ AND THE MING CHINA: THE TŪQMĀQ AND THE CHINESE RELATIONS DURING THE MING PERIOD (1394-1456)*
}

\author{
Nurlan Kenzheakhmet \\ Nazarbayev University \\ Astana, Kazakhstan \\ nurlan.kenzheakhmet@nu.edu.kz
}

\begin{abstract}
Objective: Little is known about diplomatic relations between the Jūchīd Ulūs and Ming China (1368-1644), even though some evidence of early tributary trade relations exists. The first extant Chinese account about the country of Salai (Saray) dates to around 1394, when accounts of diplomatic exchange between the Ming court and the Jūchīd Ulūs began to appear in the Ming shilu (The Veritable Records of the Ming).

Research materials: This article analyzes the Ming shilu in order to understand the character of Chinese knowledge about the Jūchīd Ulūs during their years of contact between 1394 and 1456. Additional sources like geographic accounts and maps help define the extent of Chinese knowledge about the khanate, clarify the kinds of information that the Chinese sought and the reasons why, and measure the influence of cross-cultural contact on Ming Chinese understanding of the Jūchīd Ulūs.

Results and novelty of the research: The Ming shilu suggests that at least by the end of the fourteenth and the early years of the fifteenth century, Salai (Saray) became an integral, and possibly the most important, element in the name that the Ming court used for the country of the Jūchīd Ulūs. The Persian and Mongol historians used the term Tūqmāq and Togmog to refer to the Jūchīd Ulūs, while Ming Chinese historians used the term Tuohema to refer to the Jūchīd Ulūs or the whole Dasht-i Qipchāq, in post-Mongol Central Eurasia. The diplomatic contact between Ming China and the Tuohuma occurred through the Chinese system of tribute trade during the mid-fifteenth century. Under the reign of Yongle (1402-1424), Zhengtong (1435-1449), and Jingtai (1449-1457), the foundations for a flourishing relationship between Ming China and the Jūchīd Ulūs were established. At that time, the Chinese knew the Jūchīd Ulūs by the name Salai (Saray) and Tuohuma (Tūqmāq). Despite the political turmoil that erupted after the fall of the Jūchīd Ulūs, the Chinese continued to glean new information about the Jūchīd Ulūs from envoys who arrived from Central Asia.
\end{abstract}

Keywords: Jūchīd Ulūs, Ming China, Sarāy and Salai, Özbek and Yuezubo, Tūqmāq and Tuohuma, Ming Chinese chronicles, Chinese Maps

For citation: Kenzheakhmet N. The Tūqmāq and the Ming China: The Tūqmāq and the Chinese Relations during the Ming Period (1394-1456). Zolotoordynskoe obozrenie =Golden Horde Review. 2017. Vol. 5, no. 4, pp. 770-785. DOI: 10.22378/2313-6197.20175-4.770-785

* The term Zolotaya Orda [Golden Horde]) was first used in the second half of the sixteenth century by the Russian chroniclers to refer to the city of Saray. Hence I have used the appellation Tūqmāq throughout this work. 
Various names of the Jūchīd Ulūs were in use from Mid-Fourteenth century to the Mid-Fifteenth century. The terminology used in Chinese, Persian and Turkic historical materials:

1. Wilāyat of Sarāy and Salai 撒來

It is necessary to define some of the ethnic terms in use in the Jūchīd Ulūs. By the mid-thirteenth century when the partition of the newly conquered territories was made among Chingīz's Khans sons, the Dasht-i Qipchāq was divided among the sons of Chingīz Khan's eldest son, Jūchī. The eastern territories of the Ulūs which can be called Eastern Dasht-i Qipchāq or the Left Wing (Sol Qol) of the Jūchīd's Ulūs, were originally allotted to Jūchī's eldest son Orda or Orda Ichen, while the western half or the Right Wing (Ong Qol) of the Dasht-i Qipchāq formed an integral part of the patrimony of the Jūchī's second son, Batu. In contemporary Persian, Armenian and Muslim writings, and in the records of the thirteenth and early fourteenth centuries such as the Jami' al-tawarikh, the khanate was called the 'ulūs-i Jūchī' ('realm of Jūchī' in Mongolian), Dasht-i Qipchāq (Qipchaq Steppe in Persian) or Qipchāq Bashi (Head of Qipchāq in Turkic) [32, p. 513, 521]. The designation Jūchīd Ulūs (ulūs-i Jūchī), which literally means the people of Jūchī, encompassed the nomadic population of Central Eurasia that had been brought under Jūchīd governance in the first half of the thirteenth century.

The Turkic historians and the early Ming China historians used the term Sarāy or Salai to refer to the Golden Horde. The Eastern Dasht-i Qipchāq ruled by Orda was formally subjected to the khans of Sarāy or Ulūs of Batu but practically enjoyed total independence in matters in inner affairs.

The Tārīkh-i Dūst Sultạn or Chingīz-nāma, written by Ūtamīsh Ḥājjī b. Mawlānā Dūstī in Khwārazim in ca.1555 and dedicated to Dūst Muḥammad Khān of Khwārazimian Özbek “"Arabshāhid” dynasty, Batu's Ulūs was officially known as the Sarāy Wilāyati:

Jān Bik Khānning ānāsì Tāy Duwālì Bìgim ìmd̄̄ "Yūrttaqì khānlīq Shībān Khān üghlānlārīghah takār" tib Manqutāy üghlī Khiḍr Khānnī ūndā yitib ìltib Sarāy wilāyatīndah khan qild̄̄. "Șāyin Khān üghlānlārindīn sung ül khan takhtindah khānlīq bizgā takkāndūr" tīrlār.

Tāy Duwālī Bīgim, the mother of Jān Bik Khān, decided that khanal authority in the country should pass to the line of Shībān Khān's offspring. She went and brought out Khidr Khān, the son of Manqutāy, and elevated him as khan in the Wilāyat of Sarāy. "After the descendents of Șāyin Khān, authority over that khanal seat passed to us", (the Shībānids) say [39, p. 38b-39a $]^{1}$. At the time, since the lineage of Batu had come to an end, according to the yasa [Mongol customary law] and the law of inheritance, the ultimate rule was passed on to the descendants of Shiban Khan, Jūchī's fifth son. According to Z.V. Togan (1890-1970), a Bashkurt Turk professor, many Özbek uruks in today's Turgay province, in the vicinity of "Ak Göl" [White Lake], raised to the throne, as Khidr Khān, who was a descendant of Shiban [37, p. 31].

\footnotetext{
${ }^{1}$ The usage of the term of wilāyat by Central Asian authors is notoriously diffuse, because - to employ a rather awkward distinction - it can be used as an element of either 'political' or 'territorial' vocabulary.
} 
The fourteenth century Ming China chroniclers employed the term Salai for the Jūchīd Ulūs. For instance, Ming shilu ${ }^{2}$ refers to the Jūchīd Ulūs as Salai 撒來 [25, Taizu shilu, juan 232, p. 3395]. The Ming shilu entry for the day gengchen of the fourth month of the twenty seventh year of the reign of Hongwu (11 May 1394), reads as follows: "the seven realms of the Xiyu (Western Region) are Nepal

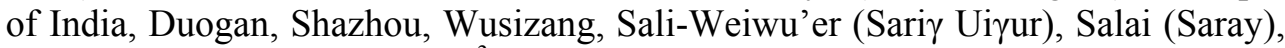
and Sama'erhan (Samarqand)"3.

Salai also occurs in the Ming shilu entry for the day kuisi of the fifth month of the seventh year of the reign of Yongle (4 July 1409):

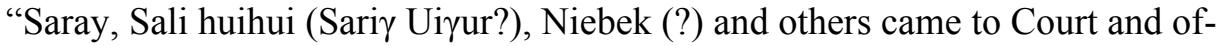
fered tribute of horses. Paper money and variegated silks, were conferred upon them" [25, Taizong shilu (Veritable records of the Taizong [Emperor] of the Ming), juan 92, p. 1223] $]^{4}$.

2. Özbek and Yuezubo 月祖伯

The Turkic people of the entire Dasht-i Qipchāq [Qipchāq steppe], from the Syr Darya River and Khwārazim to the Idil [Volga] basin and Saqlab, were termed "Özbek" during the reign of the Özbek Khan (1282-1341, r. 1313-1341), the ninth ruler of the Jūchīd Ulūs.

Özbeks are first mentioned in the work of the Ilkhanid historian Ḥamd Allāh Mustaufī Qazvīnī (born around 1280) who, in his Tārīkh-i guzìda (Selected History), describes the invation of Özbek Khan into the Ilkhanate in 1335, calling the Jūchīd Ulūs armies the "Özbeks" (Uzbakiyān), and calls the Jūchīd Ulūs "the kingdom of Özbek" (mamlakat-i Uzbaki) [45, p. 221-223 (text), p. 93 (trans.)]. Hamd Allāh Mustaufĩ Qazvīn̄ì's son Zain al-Dīn, who added the description of the events that took place in Iran between 1341 and 1390 to the Tärīkh-i guzìda, also designates the Jūchīd Ulūs ruled by Jānī Beg Khan (r. 1342-57), the son of Özbek Khan, as "the Özbek Ulūs" (ulüs-i Uzbak) [45, p. 226 (text), p. 97 (trans.)]. The ethnonym of Özbek is known from the famous Central Asian histories such as Abū al-Ghāzī Bahādur Khān's Shajara-i Türk va Moghūl and the Shajarat al-atrāk or the Tārīkh$i$ arba' ulūs by Ulügh Beg, tracing the origin of the designation Özbek to Özbek Khan [33, p. 206-207 (trans.), p. 266 (text); 26, p. 138; 6, p. 231-232; 9, p. 101, n. 75]. In the Shajara-i Türk va Moghūl, Abū al-Ghāzī Bahādur Khān relates:

"He (Özbek Khan) brought the $i l$ and ulus to the faith of Islam. Thanks to this possessor of good fortune, all the people had the honor of receiving the glory of Islam. It is after him that all the $i l$ of Jöchi were called the $i l$ of Özbek (el ulusni dīn-i islāmg்a körküzdi barča halq ol șāhib-i davlatnïng sababïndïn šaraf-i islāmg்a mušarraf boldilar andïn song barča Jochi elini Özbäk eli tedilär)" [2, p. 178 (text), 183-184 (trans.)].

\footnotetext{
${ }^{2}$ Ming shilu 明實錄 (The Veritable Records of the Ming). 133 vols. (Taipei: Zhongyang yanjiuyuan lishi yuyan yanjiusuo, 1967). Many editions exist; here we used the photolithographed version compiled by the Academia Sinica in Taiwan over the years 1962 to 1967 under the direction of Huang Zhangjian 黄彰健. It is on the Taiwan edition that this article is based.

${ }^{3}$ Chinese text: 西域之部七, 西天泥八刺國, 朵甘，沙州，烏思藏，撒立畏兀兒，撒來， 撒馬兒罕.

${ }^{4}$ Chinese text: 撒來, 撒里回回, 聶癿等來朝, 貢馬賜鈔及襲衣.
} 
It is clear that, whether these accounts reflect historical events or not, the designation Özbek began to be used as a term denoting the nomadic people of the Jūchīd Ulūs during the reign of Özbek Khan. Therefore, it may be assumed that the Jūchīd Ulūs also became known as the Özbek Ulūs after Özbek Khan's reign. The designation Yuezubo (Özbek) was also used in the Chinese sources and the Chinese maps to refer to the Jūchīd Ulūs of the fourteenth century.

This name can be found on a Chinese map entitled Yuan Jingshi dadian xibei dili $t u$ 元經世大典西北地理圖 (Map from the Jingshi dadian of the Yuan, representing countries to the northwest) of the year 1331, as Yuezubo 月祖伯, also called Yuejibie 月即別 or Yuezubo in the Yuanshi 元史 (History of the Yuan) [44, juan 117, p. 2906; 5, II, p. 6]. According to the Yuan chronicle, Yuezubo is the name of the horde or ulus of the Dasht-i Qipchāq. In Tārīkh-i Rashīdī this country is mentioned as Uzbeg ulus or Uzbegstan [10, p. 272, 366, 374].

At the end of the geographical section, the Yuan shi (History of the Yuan) offers an appendix entitled 'Xibei di fulu 西北地附錄 (countries to the northwest of the Yuan Dynasty)'. It consists of an enumeration of countries and places; almost all of which can be easily identified with place names found in the Yuan jingshi dadian dili $t u$ 元經世大典西北地理圖 (The geographical map from the Encyclopedia of Yuan dynasty Institutions), published in 1331, which describes the Mongol dominions in Central and Western Asia [5, II, p. 3-136]. According to the "Yuan shi [44, juan 63, p. 1570], the realm of the Yuezubo includes Sa'erkesi 撤耳柯思 (Circasia or Shirkasia/Cherkess), Alan 阿蘭 (Alans or Alania), Asi 阿思 (Asi/Osi, modern Ossetians), Qincha 欽察 (Qipchāq), Aluosi 阿羅思 (Rus), Buli'a'er 不里阿耳 (Bulghar), Sajila 撒吉刺 (Saqlab), Hualazimo 花刺子模 (Khwārazim), Sailan 賽蘭 (Sabran) ${ }^{5}$ ，Ba'erchihan 巴耳赤邗 (Bārchīnlīy-kand，Ba'erchili 巴耳赤利 in Jingshi dadian dili tu), Zhande 邅的 (Jend or Jand, Zhande 轳的 in Jingshi dadian dili tu). The last two cities appear on the famous Kangnido map, as Balichiyan 八里赤岩 (Bārchīnlīy-kand) and Chande 原的 (Jend) [17, p. 148-149].

In the first half of the sixteenth century, Ming Chinese chroniclers refer to the Qazaq Khanate as 額即癿, or 額即癿哈辛, the name in Ming shilu must be pronounced Ejibie, or Ejibie-Haxin, a Chinese transcription of "Özbek", or "ÖzbekQazaq" (see below).

3. The Tūqmāq and the Tuohuma

The Central Asian historians, Mongolian chroniclers and Ming China historians used the term Tūqmāq and Tuohuma to refer to the Jūchīd Ulūs [37, p. 27-29; 5, II, p. 161]. For instance, Natanzī refers to the Golden Horde as the Tūqmāq Ulūs (ūlūs-i Tūqmāq) [28, p. 138 (trans.], p. 242 (text); 29, p. 435]. The designation Tuohuma was a term used by the Ming chroniclers to refer to the Jūchīd Ulūs in 1415 [25, Taizong shilu, juan 169, p. 1890]. In his Xiyu fan'guozhi (A Record of the Barbarian Countries in the Western Region), a report of the Ming dynasty written in 1414-1415 for the Yongle emperor, Chen Cheng (1365-1457), provide a slightly different version of the account about the border of the Beshbalyq, and mentioned the country of Tuohuma [41, p. 102]. In the Ming shilu, in a report under the first year of the Zhengtong reign (1436), Toqmaq is also called as

\footnotetext{
${ }^{5}$ It must be Sabran, modern Sawran in Kazakhstan.
} 
Tuohuoma 脱火麻 [25, Yingzong shilu (Veritable Records of the Yingzong [Emperor] of the Ming), juan 24, p. 489]. The Da Ming huidian 大明會典 (Collected statutes of the Ming Dynasty), in 1587 edition, also mentions Tuohuma together with the names of other countries [8, juan 107, Chaogong 3]. Ming shi lists twenty-nine names of dimian 地面 (territories) including Tuohuma, that used to present tribute through Qumul [24, juan 332, p. 8626].

The sixteenth-seventeenth centuries Buddhist Mongolian chroniclers refer to the

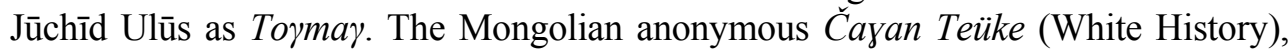
written during the reign of Qubilay Khan between 1260 and 1280, reviced and edited by Qutugtu Sečen Qong Tayijii (1540-1586), mentioned the conquest of the

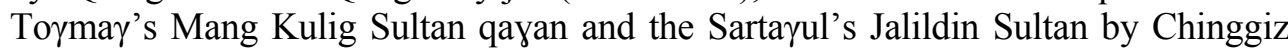
Khan [4, p. 123]. Another Mongolian work on the subject known as Bolur Toli (The Crystal Mirror), compiled by Jimbadorji, a noble from Urad banner, circa 1834 1837, mentioned Jeliledun Sultan of Sartagul and Manulan Sultan khan of Tomog. In his Erdeni-yin Tobči (The Precious Button), Sayang Sečen Qong Tayijii (1604-?) called Toymay's king as Mengülig sultan qayan [40, p. 163; p. 231 (trans.), p. 584 (text)]. Mongolian chronicle's usage of Sultan qayan or Sultan khan was identical with that of Yuan shi. The biography of Guo Baoyu, a Han Chinese from Shanxi who had been serving to the Mongols at the time of the early Mongol conquests in Central Asia, in the official history of the Yuan dynasty contains much that is of interest. In the Yuan shi, Mang Kulig Sultan qayan or Manulan Sultan khan is briefly called as Suandan Han 算端罕 (Sultan Khan). According to the Yuan shi, in 1214, Guo Baoyu 郭寶玉 accompanied Chinggis Khan on his campaigns against the Qipchāq and Naiman. The Suandan Han (Sultan Khan) of Kefucha 可弗叉 (Qipchāq) was obeyed, the Naiman country was defeated, and Guo Baoyu was involved in the taking of Xiansigan 擣思干 (Semizkend, i.e. Samarqand) [44, juan 149, p. 3522] . $^{6}$. Sayang Sečen refers to the Eastern Dasht-i Qipchāq or Jūchīd Ulūs as Toymay Ulūs [40, p. 163, 231 (trans.), p. 584 (text)]. In mentioning the Eastern Dasht-i Qipchāq, Lubsangdanjin, the author of the Altan Tobči (The Golden Button), also designates the Jūchīd Ulūs as Tormay [19, p. 90, 293].

According to Z.V. Togan, "among the Khiva Özbeks, the term (in Ebülgazi) known as 'Togma'; Baskurts 'Tuvma'; Nogay (according to the Cevdet Pasha history) 'Tokma' designated individuals without a known lineage, or fugitives to be sold as slaves, being offenders of the law" [37, p. 27].

Națanzī also employes the term Tūqmāq to refer to the armies of both Temür Malik, the son of Urus Khan, and Toqtamïsh [29, p. 336, 425].

The seventeenth century Mongolian chroniclers employed the term Toymay for the Dasht-i Qipchāq. For instance, in his Erdeni-yin Tobči, Ssanang Ssetsen refers to the nomads of the Jūchīd Ulūs during the reigns of Esen Taishi (r. 1439-1455) and the Qazaq Khaqnazar khan (r. 1538-1580), as Toymay without distinction [34, p. 113, 141-142]. In mentioning the names of the Jüchīd khans, Lubsangdanjin, the author of the Altan Tobči, also designates both the Özbek khan Muhammad Shībānī and the Qazaq Khaqnazar khan as Toymay [20, p. 90].

\footnotetext{
${ }^{6}$ Chinese text: [郭寶玉 ] 辛巳，可弗叉國唯算端罕破乃滿國，引兵據撏思干.
} 
The designation Toymay also seems to have been in use in the Ming Dynasty in the early fifteenth century. The Ming historian calls Abū'l-Khayr Khan "the king of the territory of Tuohema” (脱忽麻地面卜刺孩王) [25, Yingzong shilu (Veritable Records of the Yingzong [Emperor] of the Ming), juan 224, p. 4851].

The realm of Abū'l-Khayr Khan, the ancestor of the Shībānid Özbeks, are identified with the Tūqmāq and the Jūchīd Ulūs in Persian sources. Khvāndamīr refers to Abū'l-Khayr Khan as "the king of the Ulūs of Jūchīd Khan" (pādshāh-i ulūs-i Jūchī Khān) [18, 4: 50].

\section{The relationships between the Tūqmāq and the Ming dynasty}

As we see from the above passage, the Jūchīd Ulūs was recorded in Ming shilu as Salai, on the day gengchen of the fourth month of the twenty seventh year of the reign of Hongwu (11 May 1394) [25, Taizu shilu (Veritable Records of the Taizu [Emperor] of the Ming), juan 232, p. 3395).

Another record containing the name Salai appears in the Ming shilu entry for the day kuisi of the fifth month of the seventh year of the reign of Yongle (4 July 1409).

The first record of Tūqmāq was recorded in Ming shilu as Tuohuma, on the day of kuisi 癸巳 in the tenth Chinese lunar month in the thirteenth year of Yongle 永樂 (30 November 1415). This is a report of the $\mathrm{Li} \mathrm{Da}$ 李達 and Chen Cheng (1365-1457) written in 1414-1415 for the Yongle emperor?:

"The country (of Beshbalyq) is bounded on the east by Qāmul, on the west by Samarqand. After Temür Kuragan subjugated Samarqand, now (this country) is bounded on the west by the Tuohuma, on the north by the Oyirat ${ }^{8}$ and on the southeast by Khotan and Aduan" [25, Taizong shilu (Veritable Records of the Taizong [Emperor] of the Ming), juan 169, p. 1890] ${ }^{9}$.

In his Xiyu fan'guozhi (A Record of the Barbarian Countries in the Western Region), Chen Cheng provide a slightly different version of the account about the Tuohuma: "[the country (of Beshbalyq)] is bounded on the east by Qāmul, on the west by Samarqand. After Temür fuma (Kuragan) subjugated Samarqand, now (this country) is bounded on the west by Yangyi ${ }^{10}$, on the north-west by the Tuohuma, on the north by the Oyirat and on the south-east by Khotan and Aduan" [41, p. 102].

This pattern appears in the appendix in the Guangyutu (Broad terrestrial map) entitled Huayi jianzhi 華夷建置 (Chinese and Non-Chinese administrative division), a geographic compilation of maps and texts compiled by Luo Hongxian (1504-1564) in 1541 [21, p. 427].

Another record containing the name Tuohuoma 脱火麻 appears in the first year of the reign of Zhengtong (6 January 1437) of Ming Yingyong shilu:

"The envoys that had been sent by the three places of the Oyirat, Qāmul and Tuohuoma, and...all came to Court and offered tribute of horses and local pro-

\footnotetext{
${ }^{7} \mathrm{Li} \mathrm{Da}$ is the eunuch who went on the diplomatic mission with Chen Cheng.

${ }^{8}$ The Oyirat are the Qalmaqs as they were known in Central Asia.

9 Chinese text: 詢其國人，云：故疆東連哈密，西至撤馬兒罕，後為帖木兒駙馬侵奪. 今西至脱忽麻, 北與瓦刺相接, 東南抵于闐, 阿端.

${ }^{10}$ Yangï, modern Taraz in southern Kazakhstan.
} 
ducts. A banquet as well as paper money and other goods, as appropriate, were conferred upon them" [25, Yingzong shilu, juan 24, p. 489 $]^{11}$.

The King of Tuohuma was recorded in Ming shilu as Maheima 馬黑麻, on the day renxu of the fourth month of the eleventh year of the reign of Zhengtong (22 May 1447):

“The envoy Tumintu Maheima 秃敏秃馬黑麻 (Tümen tuy Muhammad) who had been sent by King Maheima (Muhammad Khan) of Tuohuma (Tūqmāq) and other places... all came to the Court and offered tribute of camels and horses and other products. A banquet as well as variegated silks and other goods, as appropriate, were conferred upon them" [25, Yingzong shilu, juan 153, p. 2994] ${ }^{12}$.

The name Maheima can easily be recognized as the name (Kuchuk or Kĭčìk) Muhammad (1391-1459), the khan of the Jūchīd Ulūs. In the MSL, the name of Muhammad is translated into Chinese as Maheima 馬黑麻, while the name of Mahmūd is translated as Maheimu 馬黑木 ${ }^{13}$.

The King of Tuohuma was recorded in Ming shilu as wangzi (prince), on the day xinmao of the fifth month of the eleventh year of the reign of Zhengtong (10 July 1447):

"It was ordered that the chief envoy Huozhi Maheima Tumintu 火只馬黑麻秃敏秃 (Khwāja Muhammad Tümen tuy?) take on the post of Vice Chiliarch, that the deputy envoy Dawu (Dawud?) take on the post of Commander, and that Zhemaluding (Jamal ad-Din) take on the post of Battalion Prison, who had been sent by the prince of Tuohuma" [25, Yingzong shilu, juan 154, p. 3020] $]^{14}$.

The envoy Huozhi Maheima Tumintu is mentioned again in subsequent years by the name of Tumintu Maheima 秃敏秃馬黑麻:

"The envoy Tumintu Maheima and others who had been sent by Maheima, the king of the country Tuohuma, took leave from the Court. It was ordered that they carry Imperial orders, paper money and biao-li of variegated silks, and other goods to confer, on their return, upon their king" [25, Yingzong shilu, juan 154, p. 3020$]^{15}$.

Who was Tumintu Maheima? An envoy from Samarqand, referred at least three times between 1437-1448, bore the names of Maheima Tumintu

\footnotetext{
${ }^{11}$ Chinese text:

辛西,瓦刺、哈蜜、脱火麻三地面... 等俱來朝貢馬及方物，賜宴并賜綵幣等有差.

${ }^{12}$ Chinese text:

脫忽麻等處馬黑麻王遣使臣秃敏秃馬黑麻…等來朝貢駝馬, 玉石, 諸物; 賜宴及紵絲襲 衣綵幣表裏絹布等物有差.

${ }^{13}$ In the Ming shilu, the name of Muhammad translated into Chinese as Maheima馬黑麻, while the name of Mahmūd translated as Maheimu馬黑木. In the Uighur documents Gaochang guan ke of Ming dynasty Sutan Maheimu 速壇馬黑麻 (Sultān Muhammad) was translated into Turkic as Sultan Maqemat [11, p. 62].

${ }^{14}$ Chinese text:

命脫忽麻王子遣來朝貢正使火只馬黑麻秃敏秃為副千戶，副使答兀為百戶，者馬魯丁等 俱為所鎮撫.

${ }^{15}$ Chinese text:

脱忽麻等處馬黑麻王使臣秃敏秃馬黑麻等劽辭命貟敕及綵幣表裏歸賜其王.
} 
馬黑麻秃敏秃 [25, Xuanzong shilu, juan 82], Shehei Maheima 捨黑馬黑麻 (Shakh/Sheikh Mạmmūd) [25, Yingzong shili, juan 160, p. 3119] or Shehei Maheima Tumaitu 捨黑馬黑麻秃買秃 (Sheikh Mahmūd) [25, Yingzong shilu, juan 167, p. 3232]. One of the enovys of Yemili Huozhe was also called as Maheima Tumiantu 馬黑麻秃免秃 (30 May 1435) [25, Yingzong shilu, juan 129 , p. 2566]. The first part of his Arabic title, shehei, sheikh, was used to designate a learned person, as an Arabic word it is essentially independent of religion. The last part of his "Mongol-Turkic" title is tumintu or tumaitu. Obviously both expressions are transcription of the same words: tümän tuy (ten thousand standard or banner), which marked a high rank among the nobility; military unit of ten thousand. The unit of ten thousand is used throughout the Jami'u't-tawarikh for the Turkish tümän. The subdivisions of the tümän were the ming, yüz, on. They were components of the tümän, the "divisions"of ten thousand.

The Ming shilu also mentioned an envoy from Taolaisi (Tabriz) called Dalahan shehei Maheima minhatu 打刺罕舍黑馬黑麻閩哈秃 (Tarkhān sheikh Muhammad Minghan tuy?):

"[On the day wuwu of the eighth month of the sixth year of the reign of Xuande (2 October 1431)] the envoy Dalahan shehei Maheima minhatu and others who had been sent by wanhu Yisimayin of Taolaisi all came to the Court and offered tribute and other products" [25, Xuanzong shilu, juan 82, p. 1906-1907] ${ }^{16}$.

The last part of his "Mongol-Turkic" title, minha $t u$, is transcription of the word minghan tuy (thousand standard or banner). Minghan is the Mongolian for thousand.

As for "tumintu" or "tumaitu", the title of the Maheima, I do not know whether this was a title conferred by the Tūqmāq or by the Samarqand (Timurid). Unfortunately, my efforts are confined by the limits of these few materials, and I cannot ascertain who this person was, or ascertain the situation of the administrative relationship between the Tūqmāq and the Samarqand.

The ruler of Tuohuma is referred to as king (wang) in the Ming Shilu (10 January 1453: day yichou of the twelfth month of the third year Jingtai), where it is recorded that the king of Bulahai (Abū'l-Khayr Khan) sent envoys to the Ming court and his name occurs together with Jānībek, a king of Asibie (Özbek) ${ }^{17}$ :

"The rulers (in Central Asia) all sent envoys to pay horses as tribute to (the Ming) court. They were Zhongshun wang (Loyalty and Obedience King) Daowadashili (Dawadasiri/Dawadaširi) and headman Tuotuo buhua (Toqto Buqa

\footnotetext{
${ }^{16}$ Chinese text:

宣德六年八月戊午, 讨来思万户亦思马因遣使臣打刺罕舍黑马黑麻 - 闽哈秃等来朝贡方 物.

${ }^{17}$ Chinese text:

哈密忠順王倒瓦答失里, 頭目脫脫不花; 亦力把里地面也先卜花王并妃虎都速旦, 頭目 捨刺; 土魯番地面也密力虎者王并妃右瓦兒速擅等, 頭目馬麻米兒咱等; 察力失地面也 密力虎者王姊打刺悶等, 頭目打刺癿兒的; 脫忽麻地面卜刺孩王; 賽蘭地面頭目革來壇 ；把丹沙地面頭目速魯壇馬黑木; 速魯壇牙地面頭目速兒卜撒溫; 阿思癿地面札尼癿王 ; 捨力灣乃丁地面速壇阿力王等; 阿刺冊刺地面賽你阿卜丁, 王子阿的罕沙; 并克失迷 兒, 哈刺火州, 帖力蠻, 掃蘭等一百二十一處地面頭目俱遣使來朝, 貢馬; 賜宴并綵幣 表裏紵絲襲衣等物.
} 
or Toytō Buqa) from Hami (Qamul); King Yexian Buhua (Esän Buqā Khān) and his wife Hudu sudan (Qutluq Sulțān?), and headman Shela (Shela) from the Ilibali dimian (the territory of Moghulistan) ${ }^{18}$; King Emili Huzhe (Mīr Khwāja) ${ }^{19}$ and his wife Guwa'er Sutan (Gawhar Sultānn?) ${ }^{20}$, and headman Mama mi'erza (Mamay Mirza?) et al., from Tulufan dimian (the territory of Turfan); princess Dalamen et al., who is the elder sister of Emili Huzhe (Mīr Khwāja), and headman Dalabie'erde (Dawlat Berdi?) from the Chalishi dimian (the territory of Chalish); King Bulahai (Abū'l-Khayr) from Tuohuma dimian (the territory of Tūqmāq); headman Gelaitan (Girāy Sultạn?) from Sailan dimian (the territory of Sayram); headman Sulutan Maheimu (Sultān Muhammad) from Badansha (the territory of Badakhshan); headman Su'er Busawen (Sultān Abū Sa'īd?) from Sulutanya dimian (the territory of Sultānīya); King Zhanibie (Jānībek) from Asibie dimian (the territory of Özbek); King Sutan Ali (Sulțān Ali) from Sheliwan-naiding dimian (the territory of Shirwan-i Ajam?); Prince Adehansha, the son of King Saini Abuding, from Alamula dimian (the territory of Varahamula); and headmen from 121 territories such as Keshimi'er (Kashmir), Hala Huozhou (Qara Qoja), Tieliman (Termez?), Saolan (Sawran); and so on ${ }^{21}$ [25, Yingzong shilu, juan 224, p. 4851].

To my knowledge, this is the only passage in the Yingzong section of the Ming shilu where Bulahai is mentioned as king of the Tuohuma. Bulahai is Chinese form of Abü'l-Khayr. Medieval Chinese sources translated the Arabic personal names 'Abū' into Chinese as 'bu'. For instance, Abū'said, the last Ilkhanid ruler (13161335), is mentioned in the Yuan shi as Busaiyin 不賽因 [44, juan 63, p. 1571]. Abū'said, a Timurid ruler in Transoxiana, is mentioned in the Ming shilu as Busayin 卜撒因 [25, Yingzong shilu, juan 267, p. 5676; 15, p. 211]. According to Usmanov, in the late-seventeenth century's Däftär-i Čingiz-nāmä, Abū'l-Khayr Khan is called Bolyar Khan [38, p. 116; 7, p. 37].

As we see from the above passage, the ruler of Asibie dimian (the territory of Asibie) was recorded in Ming shilu as Zhanibie, on the day of jichou in the twelfth Chinese lunar month in the year of Jingtai (1453). The name Zhanibie can easily be recognized as the name of the first Qazaq khan Jānībek (?-1480), son of Barāq Khan (r. 1425-1428) of the Āq Orda (White Horde). Asibie, Özbek, appears to represent the title of "Özbek Jānībek Khan."

However, as the record in the Ming shilu does not provide any direct evidence regarding the year of Jānībek and Girāy's separation from Abū al-Khair Khan, it may be that by 1453 Jānībek and Girāy were acting as independent kings with their own diplomatic initiatives. It was thought for long that with Barāq Khan's death Urūs Khan's line had extinguished, and Abū'l-Khayr Khan eventually conquered the Eastern Dasht-i Qipchāq and ruled over the whole Urūs Khan's house since 1428. Jānībek himself associated with the Asibie dimian (Chinese version of ulus-i

18 According to the Uighur documents Gaochang guan ke of the Ming dynasty, Shela 捨刺 was translated into Turkic as Shela. This full name is Shela Mahamushe 捨刺馬哈木捨 (Shela Maqamutsha) [11, p. 46].

${ }^{19}$ Perhaps Mīr Khwāja, the son of Khiḍr Khwāja, see: [27, p. 52].

${ }^{20}$ The $M u$ ' $i z z$ al-ansāb fi shajarat al-ansāb (The Book in Praise of Genealogies) which is a genealogy of the Chingīzid and the Tīmūrid families written in Persian in 1426-1427, mentioned Gawhar Sultān, the daughter of Shah-Jahan, see: [27, p. 52].

${ }^{21}$ For the countries' names, mentioned in this account, see: [14, p. 4-5]. 
Uzbaki), which suggests that the Qazaq Khanate should be understood as emerging as a separate political entity, centered in the Syr Darya region. After Barāq Khan's death, the Āq Orda split into several parts: the Abū'l-Khayr's Khanate, the Noyay Horde and the Qazaq Khanate.

Let us pause briefly and look at the state of affairs in the beginning of the 1430s-1440s. Together with other Shībānids, Abū'l-Khayr Khan's ancestors had lived for most of the thirteenth and fourteenth centuries in the region of Western Siberia. After the reign of Jumaduq Khan, in 1428, Abü'l-Khayr Khan established themselves in khanal authority at Tura, in the region Ibir-Sibir. According to the the Tārīkh-i Abü'l-Khayr Khānī, another general history up to Abü'l-Khayr Khan and his descendants, written in Persian by Mas'ūd Kūhistān̄, before the conquest of Syr Darya region, Abū'l-Khayr Khan ruled only over the region Ibir-Sibir until 1446.

With the help of Edigü's grandson Vaqqāṣ Bīy and another followers, Abū'lKhayr Khan now was about to finish his southward expansion into Khwārazim. In 1431/32 Abū'l-Khayr Khan attacked the brothers Mahmūd Khan and Ahmad Khan, the sons of Kuchuk Muhammad, and they met the Abü'l-Khayr Khan's army at IkriTup [46, p. 36]. Abū'l-Khayr Khan beat two brothers and captured Orda-Bazar, although Mahmūd Khan and Ahmad Khan were able to flee [23, p. 154-155; 46, p. 3637]. According to the Baḥr al-asrār fi manāqib al-akhyār, after the battle, Maḥmūd Khan and Ahmad Khan returned und ruled over they realm [31, p. 157].

Until recently it has been thought that Jānībek and Girāy's fled from Abū alKhair Khan took place in the fifties or sixties of the fifteenth century, and a large group of Özbek nomads fled from Abū al-Khair Khan's oppressive rule and became the qazaqs. I am inclined to think that when Siynaq was occupied by Abū'lKhayr Khan in 1446, Jānībek and Girāy fled to somewhere in Qazaq Steppe. Thus, Jānībek and Girāy's fled from the Syr Darya region coincided with the occupation of Sighnaq by Abū'l-Khayr Khan in 1446. Then, after ten years of vagrancy, these Qazaq fugivities settled down in the Moghulistan, the region seized by Qūzī Bāshī from Isān Bughā Khan. As K. Akishev put it, "the date of the founding (1428) of the Abü'l-Khay Khanate, should be considered as the beginning of the Özbek and the Qazaq statehood" [3, p. 132]. The Timurid historians also regarded the Jūchīd Ulūs ruled by Urus Khan (r. ca. 1368-1378), the ancestor of the Qazaq khans Jānībek and Girāy, as Özbek. In the Muntakhab altavārīkh- $i$ Mu 'inn̄i, Natanzī refers to the throne of the western wing of the Jochid Ulus, which Urus Khan captured, as "the Özbek throne" (takht-i Uzbak) [28, p. 131 (trans.), p. 242 (text)]. It should be noted that the two countries ruled by Abü'l-Khayr Khan and Jānībek Khan, respectively, were called Tuohema and Asibie in the Ming shilu. Thus, the Qazaq Khanate should be regarded as a successor state to the Barāq's branch of the Urūsid lineage, rather than as a new Qazaq state.

To our surprise, in the Ming shilu mention a Sayram chief is called Gelai 革來壇 (see above). The Chinese form Gelaitan most likely a copyist error for Gelai sutan 革來速壇, a Turkic name that would be written Girāy Sulțān, greatgrandsons of Urūs Khan, a central figure of the formation of the Qazaq Khanate. The name itself appears in the Persian sources as Gadāy in the Majma' al-ansā $b$ wa-l-ashjär, which is a genealogy of the Islamic rulers and the Central Asian dynasties written in Persian in the end of the nineteenth century. Girāy must be read for Gadāy. Gadāy is a typical Persian typographical error [1, fol. 347 (text), p. 275 (trans.)]. Sailan is either Sayram, or Sabran in Southern Kazakhstan. 
The Ming shilu entry for day guisi of the ninth month of the seventh year of the reign of Jingtai, reads as follows:

"[On the day guisi of the ninth month of the seventh year of the reign of Jingtai (25 October 1456) the envoy-commander Shanxiding (Shams ad-Din or Shamshidin) who had been sent by the countries of Hami and Tuohuma (Tūqmāq) and... all came to the Court and offered tribute of horses and local products. A banquet as well as variegated silks and other goods, as appropriate, were conferred upon them" [25, Yingzong shilu, juan 270, p. 5732 $]^{22}$.

Table of the Jūchīd Ulūs's tribute to the Ming Dynasty

\begin{tabular}{|c|c|c|c|}
\hline Year (reign year) & Name of Khanate & $\begin{array}{l}\text { Name of Khan } \\
\text { or Envoy }\end{array}$ & Sources \\
\hline 1394 (Hongwu 27) & Salai 撒來 & & Taizu shilu, juan 232 \\
\hline 1409 (Yongle 7) & Salai & & Taizong shilu, juan 92 \\
\hline 1415 (Yongle 13) & Tuohuma 脱忽麻 & & $\begin{array}{l}\text { Yingzong shilu, juan } \\
224\end{array}$ \\
\hline 1437 (Zhengtong 1) & Tuohuoma 脱火麻 & & Yingzong shilu, juan 24 \\
\hline 1447 (Zhengtong 12) & Tuohuma 脱忽麻 & $\begin{array}{l}\text { Khan: Maheima wang } \\
\text { (Muhammad Khan) } \\
\text { Envoy: Tumintu } \\
\text { Maheima (Tümen tuy } \\
\text { Muhammad) }\end{array}$ & $\begin{array}{l}\text { Yingzong shilu, juan } \\
153\end{array}$ \\
\hline 1447 (Zhengtong 12) & Tuohuma & $\begin{array}{l}\text { Wangzi (Prince) } \\
\text { Envoy: Huozhi } \\
\text { Maheima Tumintu } \\
\text { (Khwāja Muhammad } \\
\text { Tümen tuy) }\end{array}$ & $\begin{array}{l}\text { Yingzong shilu, juan } \\
154\end{array}$ \\
\hline 1453 (Jingtai 3) & Tuohuma & $\begin{array}{l}\text { Bulahai wang } \\
\text { (Abū'l-Khayr Khan) }\end{array}$ & $\begin{array}{l}\text { Yingzong shilu, juan } \\
224\end{array}$ \\
\hline 1456 (Jingtai 7) & Tuohuma & $\begin{array}{l}\text { Shanxiding (Shams } \\
\text { ad-Din) }\end{array}$ & $\begin{array}{l}\text { Yingzong shilu, juan } \\
270\end{array}$ \\
\hline
\end{tabular}

After 1456, Tuohuma disappearred from Ming shilu. The Eastern Tūqmāq began to split into three parts: the "Özbek Shībān", the "Özbek Qazaq" and the "Özbek Mangit". According to Z.V. Togan, the division of the Özbeks into the "Özbek", the "Qazaq" and the "Mangit-Nogay" took place not in the Idil basin but while they were living in the Syr Darya basin [37, p. 30]. At that time, the western regions of today's Kazakhstan, as well as Bashkurt and Tura lands, became subjected to Mangit-Nogay in their entirety. In 1486, Muhammad Shībānī, the real founder of Shībānid power, took control of some fortresses of Khwārazim. At the turn of the sixteenth century, Muhammad Shībānī led his fellow Shībānids and their non-Chingīzid tribal supporters' invasion of the Tīmūrid-governed Māwarā al-nahr, conquered Samarqand from Babur in 1500.

In the first half of the sixteenth century, the Ming Chinese chroniclers refer to the Qazaq Khanate as 額即癿, or 額即癿哈辛. The name in Ming shilu must be

22 Chinese text: 癸巳哈密并脱忽麻等處使臣指揮陝西丁…等來朝貢馬及方物; 賜宴并綵假表裏等物有差. 
pronounced as Ejibie, or Ejibie-Haxin, a Chinese transcription of "Özbek", or "Özbek-Qazaq" [16, p. 135-138].

Regarding Ejibie-Haxin, Ming shilu reports that (16 March 1532):

“As for Ejibie-Haxin, according to a report by the Libu 禮部 (Ministry of Rites), [his state] is a Dada huiyi 鞋靼回夷 (a foreign state of Tatar Muslims)” [25, Shizong shilu, juan 135, p. 3192].

Another Ming source, Shuyu zhouzi lu 殊域周咨錄 (Informative records on countries far away), completed by Yan Congjian 嚴從簡 in 1574, contains an account of Ejibie-Haxin that includes the following:

"The king of Haxin, formerly living in the Northern Mountains of Samarqand in Ejibie (Özbek) territory, was also known as being half Dazi (half Tatar) ${ }^{23}$. Earlier, he had sent an envoy, Tursun, to present tribute and check [information] with the archives. So, Haxin of today is the Haxin of before, which was at that time known as a niche of the Northern Mountains, which now has the place name of Ejibie (Özbek)" (43, juan15: 492f).

The Ming Chinese sources refer to the Shībānid Dynasty as Sama'erhan (撒馬兒 罕, Samarqand) or Sama'erhan dimian (撒馬兒罕地面, the Samarqand realm), for the city of Samarqand was its capital in the reviewed period, another name for the Shībānid Dynasty. The designation Samarqand, as a generic term for the Tīmūrid-governed Māwarā al-nahr, continued to be used in the Shībānid-governed Māwarā al-nahr in the Ming sources.

In order to clarify this ambiguity, Ming Chinese historians refer to the khans of the Shībānid Dynasty as the Sama'erhan fanwang (Foreign king of Samarqand):

The "Wuzong shilu" (Veritable Records of the Wuzong [Emperor] of the Ming) transliterated the name of Muhammad Shākhī Bīk/Shaybak (or Shībānī), the first ruler of the Shībānid Khanate, as Shayibie 沙亦癿. The Ming shilu refers to Shībān̄̄ as “fanwang Shayibie 番王沙亦癿”, the “foreign king Shākhī Bīk" of Sama'erhan 撒馬兒罕 (Samarqand), on the day of guimao 癸印 in the eleventh Chinese lunar month in the third year of the reign of Zhengde (December 1, 1508):

“The envoy Maheima Huozhe 馬黑麻火者 (Muhammad Khwāja) and others who had been sent by Shayibie (Shākhī Bīk), the barbarian king of Sama'erhan (Samarqand), presented camels and horses, offered tribute of local products. Variegated silks and other goods, as appropriate, were conferred upon them" [25, Wuzong shilu, juan 44, p. 1012] $]^{24}$.

\section{Conclusion}

Ming shilu suggests that at least by the end of the fourteenth and the early years of the fifteenth century Salai (Saray) became an integral (and possibly the most important) element in the name that the Ming court used for the country of the Jūchīd Ulūs. The Persian and the Mongol historians used the term Tūqmāq and Togmog to refer to the Jūchīd Ulūs, while the Ming China historians used the term Tuohema to refer to the Jūchīd Ulūs or the whole Dasht-i Qipchāq in the post-Mongol Central Eurasia. The diplomatic contact between Ming China and the Tuohuma occurred

\footnotetext{
${ }^{23}$ Dazi 達子, the other name for Tatars (Mongols), partly survived in the popular language as Dazi.

${ }^{24}$ Chinese text:

撒馬兒罕番王沙亦癿王等各遣使馬黑麻火者等貢馬駝及方物; 賜綵叚等物有差.
} 
through the Chinese system of tribute trade during the first half of the fifteenth century. Under the reign of Yongle (1402-1424), Zhengtong (1435-1449) and Jingtai (1449-1457), the foundations for a flourishing relationship between Ming China and the Jūchīd Ulūs were established. At that time, the Chinese knew the Jūchīd Ulūs by the name Salai (Saray) and Tuohuma (Tūqmāq). Despite the political turmoil that erupted after the fall of the Jūchīd Ulūs, Chinese gleaned new information about the Jūchīd Ulūs from envoys who arrived from Central Asia.

\section{REFERENCES}

1. Abd al-Qadir ibn Muhammad-Amin. Majma al-ansab va-l-ashjar. Trans. and eds. Sh.H. Vohidov. A.K. Muminov, B.B. Aminov. Istoriya Kazakhstana v persidskikh istochnikakh [The History of Kazakhstan in Persian Sources]. Vol. II. Almaty, Dayk, 2005. (In Persian, Russian)

2. Aboul-Ghâzi Béhâdour Khân. Histoire des Mongols et des Tatares. Trans. Petr I. Demaisons. St. Petersburg, 1871-1874; repr., Amsterdam, Philo, 1970. (In French)

3. Akishev K., Khabdulina M. Kazakhskoe gosudarstvo XV-XVI vv.: etnicheskaya territoriya, pamyatniki kultury [The Kazakh State of the $15^{\text {th }}-16^{\text {th }}$ centuries: The Ethnic Territory, Cultural Monuments]. Euraziyskoe soobshestvo: obshestvo, politika, kultura [The Eurasian Community: Society, Politics, Culture]. №1 (21), 1998. (In Russian)

4. Belaya Istoriya. Mongolskiy istoriko-pravovoy pamyatnik XIII-XIV vv. [The White History. The Mongolian Historical and Legal Monument of the $13^{\text {th }}-14^{\text {th }}$ centuries]. Vanchikova Ts.P. (ed.). Ulan-Ude, 2001. (In Russian)

5. Bretschneider E. Mediaeval Researches from Eastern Asiatic Sources: Fragments towards the Knowledge of the Geography and History of Central and Western Asia from the $13^{\text {th }}$ to the $17^{\text {th }}$ Century. London, Trübner, 1910 [2 vols.].

6. Col. Miles. The Shajrat ul Atrak or Genealogical Tree of the Turks and Tatars. London, 1838.

7. Deftere Chyngyz-name [Däftär-i Čingiz-nāmä]. Kazan, 2000. (In Tatar)

8. Da Ming huidian 大明會典 [Collected Statutes of the Ming Dynasty], by Li Dongyang 李東陽 (1447-1516). Beijing, Zhonghua, 1988. (In Chinese)

9. DeWeese D. Islamization and Native Religion in the Golden Horde: Baba Tükles and Conversion to Islam in Historical and Epic Tradition. University Park, PA, Pennsylvania State University Publ., 1994.

10. Elias Ney (ed.), E. Denison Ross (tr.). The Tārīh-i Rasīdī of Mīrzā Muhammad Haidar, Dughlát: A History of the Moghuls of Central Asia. London, Sampson Low, 1895 [repr. Leipzig 2005].

11. Hu Zhenhua 胡振華, Huang Runhua 黃潤華, Mingdai wenxian “Gaochang guan $k e$ (Huihu wengao yong Lading wenzi yizhu) 明代文獻“高昌館課” (回鶻文稿用拉丁文字譯注). Beijing, Zhongyang minzu xueyuan keyanchu, 1980 . (In Chinese)

12. Istoriya Kazakhstana v Persidskikh Istochnikakh, III [The History of Kazakhstan in Persian Sources. Vol. III]. Almaty, Dayk, 2006. (In Russian)

13. Johann Schiltberger. The Bondage and Travels of Johann Schiltberger: A Native of Bavaria, in Europe, Asia, and Africa, 1396-1427. Trans. J. Buchan Telfer. London, 1879.

14. Kamāl al-Dīn 'Abd al-Razzāq Samarqandī. Maṭla 'i sa' dain va majma 'i baḥrain. Sbornik materialov, otnosyashchikhsya k istorii Zolotoy ordy, II. Izvlecheniya iz Persidskih sochineniy sobrannye V.G. Tizengauzenom [Collected Materials Related to the Golden 
Horde History. Vol. II: Extracts from the Persian Sources Collected by V.G. Tiesenhausen]. Moscow-Leningrad, Akademiya nauk SSSR, 1941. (In Persian, Russian)

15. Kauz R. Politik und Handel zwischen Ming und Timuriden: China, Iran und Zentralasian im Spätmittelalter. Wiesbaden, Reichert verlag, 2005. (In German)

16. Kenzheakhmet N. The Qazaq Khanate as Documented in Ming Dynasty Sources. Crossroads - Studies on the History of Exchange Relations in the East Asian World. 2014, Vol. 8, pp. 131-156.

17. Kenzheakhmet N. The Place Names of Central Asia in the Kangnido. Journal of Asian History (49) 2015, 1/2, pp. 141-160.

18. Khvāndamīr, Ghiyās al-Dīn b. Humām al-Dīn. Tārīkh-i Habīb al-siyar fi akhbār-i afrād-i bashar. Edited by Jalāl al-Dīn Humā’̄̄. 4 vols. Tehran, Kitābfurūshī-i Khayyām, 1333/1954-55. $3^{\text {rd }}$ repr. ed., 1362/1984. (In Persian)

19. Lubsan Danzan. Altan Tobči [The Golden Tale]. Trans. N.P. Shastina. Moscow, 1973. (In Mongolian, Russian)

20. Lubsangdanjin. Altan Tobči: eine mongolische Chronik des XVII. Jahrhunderts von Blo bzan bstan'jin. Ed. Hans-Peter Vietze and Gendeng Lubsang. Tokyo: Institute for the Study of Languages and Cultures of Asia and Africa, 1992. (In German)

21. Luo Hongxian. Guang yutu [Broad Terrestrial Map]. Taibei, 1969. (In Chinese)

22. Materialy po istorii kazakhskikh khanstv XV-XVIII vekov [Materials on the History of the Kazakh Khanates of the $15^{\text {th }}-18^{\text {th }}$ centuries]. Comp. and trans. C.K. Ibragimov and others. Alma-Ata, Nauka Kazakhskoy SSR, 1969. (In Russian)

23. Mas'ūd Kūhistānī. Tārīkh-i Abū'l-Khayr Khānī. Materialy po istorii kazakhskikh khanstv XV-XVIII vekov [Materials on the History of the Kazakh Khanates of the $15^{\text {th }}-18^{\text {th }}$ centuries]. Comp. and trans. C.K. Ibragimov and others. Alma-Ata, Nauka Kazakhskoy SSR, 1969. (In Persian, Russian).

24. Ming shi 明史 [History of the Ming], by Zhang Tingyu 張廷玉 (1762-1755). Taipei, Guofang yanjiuyuan Ming shi biancuan weiyuanhui, 1962. (In Chinese)

25. Ming shilu 明實錄 [The Veritable Records of the Ming]. Taipei, Zhongyang yanjiuyuan lishi yuyan yanjiusuo, 1964-1967. (In Chinese)

26. Мирзо Улуғбек. Турт улус тарихи. Тошкент, 1994. (In Uzbek)

27. Mu izz al-ansāb fĩ shajarat al-ansāb, facsimile ed., trans. Sh.Kh. Vohidova and others. Istoriya Kazakhstana v persidskikh istochnikakh 3 [The History of Kazakhstan in Persian Sources. Vol. III]. Almaty, Dayk, 2006. (In Persian)

28. Naṭanzī, Mu 'īn al-Dīn. Muntakhab al-tavārīkh-i Mu'īnī. Sbornik materialov, otnosyashchikhsya $k$ istorii Zolotoy ordy, II. Izvlecheniya iz Persidskih sochineniy sobrannye V.G. Tizengauzenom [Collected Materials Related to the Golden Horde History. Vol. II: Extracts from the Persian Sources Collected by V.G. Tiesenhausen]. MoscowLeningrad, Akademiya nauk SSSR, 1941. (In Persian, Russian)

29. Națanzī, Mu'īn al-Dīn. Muntakhab al-tavārīkh-i Mu īnī. Edited by Jean Aubin. Tehran, Khayyam, 1336/1957. (In Persian) French)

30. Pelliot P. Le Hōja et le Sayyid Husain de l'histoire des Ming. Leiden, 1948. (In

31. Qazaqstan Tarihy [History of Kazakhstan], vol. 2: Qazaqstan Songghy Orta Ghasyrlar Dawirinde [Kazakhstan in the Late Medieval Period]. Comp. by Valikhanov Institute of History and Ethnology, Margulan Institute of Archaeology of Kazakhstan. Almaty, Atamura, 1998. (In Kazakh)

32. Rashiduddin Fazlullah. Jami 'u't-tawarikh (Compendium of Chronicles): A History of the Mongols. Translated by W.M. Thackston. 3 pts. Sources of Oriental Languages and Literatures 45. [Cambridge, MA], Department of Near Eastern Languages and Civilizations, Harvard University, 1998-1999.

33. Shajarat al-atrāk. Sbornik materialov, otnosyashchikhsya k istorii Zolotoy ordy, II. Izvlecheniya iz Persidskih sochineniy sobrannye V.G. Tizengauzenom [Collected Materials Related to the Golden Horde History. Vol. II: Extracts from the Persian Sources Collected 
by V.G. Tiesenhausen]. Moscow-Leningrad, Akademiya nauk SSSR, 1941. (In Persian, Russian)

34. Ssanang Ssetsen. Erdeni-yin Tobci ('Precious Summary'): A Mongolian Chronicle of 1662. Ed. M. Gō, I. de Rachewiltz, J.R. Krueger, and B. Ulaan, vol. 1: The Urga Text. Canberra, The Australian National University, 1990.

35. Sbornik materialov, otnosyashchikhsya $k$ istorii Zolotoy ordy, II. Izvlecheniya iz Persidskih sochineniy sobrannye V.G. Tizengauzenom [Collected Materials Related to the Golden Horde History. Vol. II: Extracts from the Persian Sources Collected by V.G. Tiesenhausen]. Moscow-Leningrad, Akademiya nauk SSSR, 1941. (In Russian).

36. Tauarih-i guzida-yi nūsrat-name. Qazaqstan tarihy turaly türk derektemeler, vol. 1, XV-XIX Gasyrlar šyğarmalarynan üzíndíler. Trans. and ed. M.Q. Äbuseyítova. Almaty, Dayk, 2006. (In Kazakh)

37. Togan Z.V. The Origins Kazaks and the Özbeks. The Central Asia Reader: The Rediscovery of History. Ed. H.B. Paskoy. New York/London, M.E. Sharpe, 1994.

38. Usmanov M.A. Tatarskie istoricheskie istochniki XVII-XVIII vv. [Tatar Historical Sources of the $17^{\text {th }}-18^{\text {th }}$ centuries]. Kazan, Kazan State Universitet Publ., 1972. (In Russian)

39. Ūtamīsh Hājjjī. Tārīkh-i Dūst Sulțān, ed. and tr. V.P. Yudin, with M.Kh. Abuseitova, as Chingiz-Name. Almaty, Ghylym, 1992. (In Turkic, Russian)

40. Wulan. "Menggu yuanliu" yanjiu [The Studies of "Erdeni-yin Tobči”]. Shenyang, Liaoning minzu chubanshe, 2000. (In Chinese)

41. Xiyu fan'guo zhi 西域番國誌 [A Record of the Barbarian Countries in the Western Region], by Chen Cheng 陳誠 (jinshi 1394). Beijing, Zhonghua, 2000. (In Chinese)

42. Xiyu xingcheng $j i$ 西域行程記 [Record of a Journey to the Western Regions], by Chen Cheng 陳誠 (jinshi 1394). Beijing, Zhonghua, 2000. (In Chinese)

43. Yan Congiian 嚴從簡 (jinshi 1559). Shuyu zhouzi lu 殊域周咨錄 [Informative Records on Countries far away]. Beijing, Zhonghua, 2000. (In Chinese)

44. Yuan shi 元史 [The History of the Yuan], comp. by Song Lian 宋廉 (1310-1381). Beijing, Zhonghua, 1976. (In Chinese)

45. Zain al-Dīn b. Hamd Allāh Mustaufĩ Qazvīn̄̄. Tārīkh-i guzīda. Sbornik materialov, otnosyashchikhsya $k$ istorii Zolotoy ordy, II. Izvlecheniya iz Persidskih sochineniy sobrannye V.G. Tizengauzenom [Collected Materials Related to the Golden Horde History. Vol. II: Extracts from the Persian Sources Collected by V.G. Tiesenhausen]. MoscowLeningrad, Akademiya nauk SSSR, 1941. (In Persian, Russian)

46. Zaytsev I.V. Astrakhanskoe khanstvo [The Astrakhan Khanate]. Moscow, 2004. (In Russian)

About the author: Nurlan Kenzheakhmet - Dr. Sci. (History), Visiting Professor of Department of Kazakh Language and Turkic Studies, School of Humanities and Social Sciences, Nazarbayev University (53, Kabanbay batyr ave., Astana 010000, Kazakhstan). E-mail: nurlan.kenzheakhmet@nu.edu.kz 


\title{
ТУКМАК И МИНСКИЙ КИТАЙ: ОТНОШЕНИЯ МЕЖДУ ТУКМАК И КИТАЕМ В МИНСКИЙ ПЕРИОД (1394-1456)
}

\author{
Нурлан Кенжеахмет \\ Назарбаев Университет \\ Астана, Казахстан \\ nurlan.kenzheakhmet@nu.edu.kz
}

\begin{abstract}
Цель исследования: мало что известно о дипломатических отношениях между улусом Джучи и Минским Китаем (1368-1644), несмотря на наличие некоторых сведений о ранних данническо-торговых отношениях. Первый сохранившийся китайский отчет о стране Салай (Сарай) датируется приблизительно 1394 годом, а отчеты о дипломатических обменах между Мин и улусом Джучи впервые появляются в «Мин шилу» («Доподлинные хроники династии Мин»).

Материалы исследования: в данной статье анализируется содержание «Мин шилу» с целью понять характер китайских сведений об улусе Джучи в период контактов между 1394 и 1456 годами. Такие дополнительные источники, как географические отчеты и карты, помогают определить степень осведомленности о ханстве, прояснить, какой тип информации китайцы искали, и для чего, и оценить влияние межкультурного контакта на понимание Минским Китаем улуса Джучи.

Результаты и новизна исследования: «Мин шилу» наводит на мысль, что по крайней мере к концу XIV и первым годам XV века Салай (Сарай) стал неотьемлемым (и, возможно, важнейшим) элементом названия, которое Минский двор использовал по отношению к улусу Джучи. Персидские и монгольские авторы использовали термин Тукмак и Тогмог в отношении к улусу Джучи, тогда как авторы Минского Китая использовали термин Туохума в отношении Джучидского улуса или всего Дашт-и Кипчака в пост-монгольской Центральной Азии. Дипломатический контакт между Минским Китаем и Туохума проходил в рамках китайской системы даннической торговли в течение первой половины XV века. В правления Юнлэ (1402-1424), Чжу Цичжэня (1435-1449) и Чжу Циюя (1449-1457) были установлены плодотворные отношения между Минским Китаем и улусом Джучи. В это время китайцы знали улус Джучи под именем Салай (Сарай) и Туохума (Тукмак). Несмотря на политическую нестабильность, возникшую после распада улуса Джучи, китайцы получали новые сведения об улусе Джучи от посланников, прибывавших из Центральной Азии.
\end{abstract}

Ключевые слюва: улус Джучи, Минский Китай, Сарай и Салай, Узбек и Юэдзубо, Тукмак и Туохума, хроники Минского Китая, китайские карты

Для цитирования: Kenzheakhmet N. The Tūqmāq and the Ming China: The Tūqmāq and the Chinese Relations during the Ming Period (1394-1456) // Золотоордынское обозрение. 2017. Т. 5, № 4. C. 770-785. DOI: 10.22378/2313-6197.2017-5$4.770-785$

Сведения об авторе: Нурлан Кенжеахмет - доктор исторических наук, приглашенный профессор Отделения казахского языка и тюркологии, школа гуманитарных и социальных наук, Назарбаев Университет (53, просп. батыра Кабанбая, Астана 010000, Казахстан). E-mail: nurlan.kenzheakhmet@nu.edu.kz

Поступила 05.07.2017 Принята к публикации 25.11.2017

Опубликована 29.12.2017 